http://revped.ise.ro

Print ISSN 0034-8678; Online ISSN: 2559 - 639X

\title{
THE MATHEMATICS CURRICULUM FOR LOW SECONDARY EDUCATION: BALANCING BETWEEN MODERN AND TRADITIONAL PERSPECTIVES
}

PROGRAMA DE MATEMATICĂ PENTRU GIMNAZIU: UN ECHILIBRU ÎNTRE MODERN ȘI TRADIȚIONAL

\section{Luminița CATANĂ}

\author{
Journal of Pedagogy, 2018 (2), 7 - 24 \\ https://doi.org/10.26755/RevPed/2018.2/7
}

The online version of this article can be found at: http://revped.ise.ro/category/2018-en/

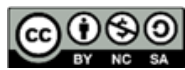

This work is licensed under the Creative Commons Attribution-NonCommercial-ShareAlike 4.0 International License. 94042, USA.

Published by:

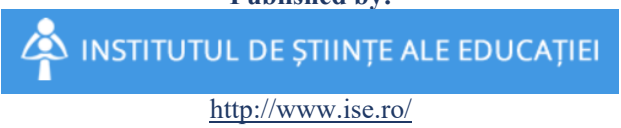

http://www.ise.ro/

Further information about Revista de Pedagogie - Journal of Pedagogy can be found at:

Editorial Policy: http://revped.ise.ro/editorial-policy/

Author Guidelines: http://revped.ise.ro/the-writer-guide-2/ 


\section{STUDII TEORETICE}

\section{PROGRAMA DE MATEMATICĂ PENTRU GIMNAZIU: UN ECHILIBRU ÎNTRE MODERN ŞI TRADI IONAL}

\section{Lumini a Catană*}

Institutul de Ştiin e ale Educa iei,

Bucureşti, România

luminita.catana@ise.ro

\section{Rezumat}

După intrarea în vigoare, în 2017, a noii programe de matematică pentru gimnaziu, s-a constatat că pot apărea diferen e semnificative între curriculumul oficial, gândit de conceptorii programei şcolare respective, şi curriculumul interpretat de profesori şi aplicat la clasă, chiar şi atunci când profesorii au participat la cursuri de abilitare curriculară. Aceste diferen e pot fi determinate de factori precum obişnuin ele de predare, nivelul clasei, manualul utilizat sau chiar evaluările na ionale. Pornind de la ideea generală că este necesar ca profesorii să decodifice corect şi mai ales să accepte noua viziune de construc ie a cunoaşterii matematice din programa şcolară, articolul detaliază aspectele noi ale programei de matematică de gimnaziu. Prezentarea acestora este raportată la fiecare sec iune a programei, insistând pe diferen ele fa ă de varianta anterioară. Articolul poate fi util atât furnizorilor de programe de perfec ionare didactică a profesorilor de matematică din gimnaziu, cât şi profesorilor care doresc să elaboreze diverse resurse didactice pentru disciplina matematică, nivel gimnazial, în acord cu noua programă.

Cuvinte-cheie: Didactica matematicii, programa de matematică pentru gimnaziu.

\section{Abstract}

After new math curriculum for the middle school ( $5^{\text {th }}-8^{\text {th }}$ grades) came into force, in 2017, it was found that significant differences between the formal curriculum,

* Cercetător ştiin ific dr., Institutul de Ştiin e ale Educa iei, Bucureşti, România. 
thought by school curriculum designers, and the curriculum interpreted by teachers and applied in class, may appear, even when teachers have participated in curricular training courses. These differences can be determined by factors such as teaching habits, class level, manual used, or even the national exams at the end of the $8^{\text {th }}$ grade. Starting from the general idea that it is necessary for teachers to decode correctly and to accept the new vision of constructing mathematical knowledge using the curriculum, this paper details the new aspects of the middle school mathematics. Their presentation is reported for each section of the program, insisting on the differences from the previous version. The article could be useful to providers of didactic training programs for middle school mathematics teachers, as well as to teachers who wish to design and develop various didactic resources for mathematics, in accordance to the new curriculum.

Keywords: Didactics of mathematics, math curriculum for middle school.

\section{Introducere}

Unul dintre scopurile esen iale ale şcolii este acela de a sus ine şi stimula dezvoltarea cognitivă şi noncognitivă armonioasă a elevilor, pe măsura poten ialului de care aceştia dispun. Programa de matematică pentru gimnaziu, aprobată recent prin OMEN nr. 3393/28.02.2017, este fundamentată pe această idee şi are în vedere formarea conceptelor disciplinare în mod progresiv şi intuitiv, precum şi formarea unor deprinderi, atitudini şi valori specifice disciplinelor exacte, utilizând experien ele anterioare ale elevilor şi exemplele disponibile din mediul înconjurător. Motivul principal pentru înlocuirea programei anterioare (din 2009) a fost că aceasta era considerată prea dificilă, solicitând multe informa ii, dar şi deprinderi complexe, care nu erau dezvoltate corespunzător până la finalul clasei a VIII-a, mai ales în cazul elevilor considera i de nivel mediu.

Conform documentelor oficiale, la finalul ciclului gimnazial, un absolvent trebuie să de ină competen ele - cheie la un nivel func ional (Repere pentru proiectarea şi actualizarea curriculumului na ional, 2016, pp. 7-8). În această structură, competen a matematică fundamentează dimensiunea cognitivă şi sus ine, prin tehnici şi procedee specifice disciplinei, dar într-o pondere ceva mai redusă, alte dimensiuni ale profilului absolventului de învă ământ gimnazial. 
Articolul îşi propune să expliciteze componentele programei în uz, utilizând în acest scop descrieri şi exemple, mai ales pentru temele care se vor preda la altă clasă gimnazială sau altfel decât în programa precedentă.

\section{Viziunea proiectării programei de matematică pentru gimnaziu}

În opinia psihologului american Howard Gardner, ,,[d]e la ideile care se formează intuitiv şi care adesea reprezintă concep ii greşite, elevii trebuie să ajungă la un set mai sofisticat de concepte şi teorii. În locul întipăririlor care nu înseamnă prea mult pentru nişte observatori sofistica i, ei trebuie să dobândească noi instrumente, cele ale câtorva discipline cheie, şi trebuie să folosească aceste instrumente pentru a ob ine întipăriri mai bune" (Gardner, 2005, p. 169), prin ,întipăriri” în elegând concepte disciplinare sau supradisciplinare, conceptele fiind, la rândul lor, reprezentări mentale ale no iunilor utilizate - toate acestea având scopul de a reordona cunoaşterea personală, de a analiza şi interpreta impresii, observa ii, fapte, teorii şi modele. Asemenea altor psihologi şi pedagogi, Gardner atrage aten ia că informa iile, deprinderile sau competen ele pe care elevii nu le valorizează în via a de zi cu zi sau în şcoală, riscă să se piardă. Ideea formulată de el este în concordan ă cu defini ia competen ei-cheie matematică, care include aspectul aplicării în via a cotidiană a elementelor specifice disciplinei. Acesta este motivul pentru care programa de matematică destinată învă ământului gimnazial subliniază ,necesitatea relevan ei, pentru elevi, a elementelor de con inut" din programă, chiar din prima sec iune a programei (în Nota introductivă).

Învă area matematicii în şcoală nu ar trebui să însemne o specializare timpurie a elevilor, ci un mijloc prin care să li se ofere acestora accesul la această disciplină. Prin matematica de gimnaziu nu se urmăreşte numai realizarea unui progres al competen elor specifice sau acumularea de informa ii în domeniu, ci şi formarea unor elevi cu un spirit deschis pentru cunoaştere, care să utilizeze achizi iile specifice matematicii pentru a în elege mai bine lumea înconjurătoare. De aceea, prin modul în care a fost gândită actuala programă, s-a inten ionat simplificarea matematicii predate în gimnaziu, nu atât prin reducerea elementelor de con inut, cât prin evitarea abordării strict 
teoretice a no iunilor matematice. Cunoaşterea matematică se construieşte treptat, pornind de la situa ii de via ă cunoscute elevilor, de la exemple intuitive, obiecte şi imagini, mai ales atunci când sunt introduse no iuni noi.

Sus inând aceeaşi idee a introducerii intuitive a no iunilor noi, psihologul american Jan Visser, unul dintre specialiştii renumi i în dezvoltarea învă ării, spunea că ,cei mai mul i oameni cred că ei ştiu ce este învă area, dar se pare că niciunul nu ştie pe de-a-ntregul. De aici, nevoia de a pune toate viziunile împreună, de ale face să interac ioneze şi de a încerca să ne ridicăm deasupra adevărurilor limitate con inute de viziunea fiecărui individ" (Visser \& Visser-Valfrey, 2008, p. 1 - tr.a.). Visser realizează o frumoasă analogie cu o poveste indiană mai veche, despre un elefant aflat într-o încăpere total întunecată şi cu care vin în contact, pe rând, diverşi oameni. Fiecare poate descrie ulterior, pe baza percep iei sale senzoriale, o caracteristică fizică a elefantului; numai punând împreună toate percep iile senzoriale individuale, cineva ar putea să-şi facă o impresie cât de cât apropiată de realitate, referitoare la felul în care arată respectivul animal. Probabil că în aceeaşi situa ie se va afla un elev la începutul ra ionamentelor de la geometrie: va sesiza păr i ale unei situa ii reale sau ale unei probleme, fără a în elege ansamblul. Concluzia ar fi aceasta: pentru a-şi forma conceptele corect, unui elev ar trebui să i se prezinte no iunea respectivă în diferite ipostaze, în diverse imagini, pe cazuri reale sau pe modele tridimensionale, în mediul virtual etc.; elevul ar trebui să observe, să discute, să măsoare, apoi să încerce să formuleze defini ii şi reguli, să realizeze cât mai multe conexiuni între no iuni şi să utilizeze în aplica ii practice noile concepte care i-au fost prezentate. De exemplu, mul i elevi nu pot preciza forma unei sec iuni plane într-un corp, deoarece nu au în via a cotidiană suficiente experien e personale de acest tip. De aceea, modelele tridimensionale (reale sau virtuale) devin absolut necesare, împreună cu exersarea deprinderii de a desena, de a reprezenta grafic aceste modele. Indiferent de natura unui concept, numai după suficiente exemple şi aplica ii se poate trece la organizarea experien ei acumulate în jurul unor elemente teoretice, făcând pasul către formalizările respective.

Modul de abordare a conceptelor într-o manieră inductivă se poate realiza urmărind etapele propuse de H. Klausmeier (Klausmeier, 1976, apud Ionescu \& Bocoş, 2017, p. 81): 
1. Nivelul concret de prezentare a no iunii presupune observarea şi recunoaşterea unor obiecte, fenomene, caracteristici etc., întâlnite anterior. Prin intermediul sim urilor, elevul ia contact cu no iunea respectivă. În cazul geometriei mai ales, conceptele sunt ideale şi poate că de aceea sunt necesare mai multe exemple din mediul apropiat, pentru studiu. În cazul algebrei, sunt necesare exemple numerice prin care elevul să în eleagă rela iile sau situa iile respective. La acest nivel este atribuită denumirea no iunii şi se face distinc ia fa ă de alte no iuni apropiate. De exemplu, elevul poate să identifice forma de dreptunghi într-o coală de hârtie, într-un tablou sau în tăblia unei mese, dar nu poate formula defini ia dreptunghiului.

2. Nivelul identificării presupune recunoaşterea obiectului, ideii, fenomenului, indiferent de ipostaze şi de modul de percepere. De exemplu, elevul recunoaşte un patrulater într-o reprezentare, indiferent că acesta este un patrulater particular (pătrat, romb, dreptunghi, trapez, paralelogram) sau, dimpotrivă, unul oarecare. Acest nivel presupune deja opera ii de clasificare şi de organizare a sistemului de no iuni. De exemplu, în situa ia descrisă mai sus, elevul recunoaşte în reprezentarea particulară ,trapez” un tip particular de patrulater.

3. Nivelul clasificator este nivelul la care un elev poate să identifice două elemente distincte sub acelaşi termen, pe baza unor atribute deja cunoscute. De exemplu, poate identifica patrulatere inscriptibile diferite ca formă sau dimensiuni sub denumirea de ,patrulatere inscriptibile”; el observă că acestea sunt convexe, dar în elege că această observa ie nu este suficientă. Elevul nu poate da încă o regulă pentru a construi aceste tipuri de patrulatere şi nici nu le poate defini.

4. Nivelul formal este nivelul la care conceptul este bine definit şi elevul poate formula criterii, reguli, formule şi teoreme ataşate. Acesta este nivelul de la care conceptul devine operant în rezolvarea de probleme (de exemplu, constată pe baza unor măsurători sau poate să demonstreze că un patrulater este inscriptibil dacă unghiurile opuse sunt complementare sau dacă unghiurile formate de laturile opuse şi diagonale sunt egale; elevul cunoaşte şi aplică aceste reguli în rezolvarea unor probleme). 
prin exemple observabile care să evite întipăririle greşite, prin exemple suficient de diversificate, pentru a nu induce confuzii. De exemplu, dacă pentru numerele divizibile cu 3 se dau ca exemple numai numere care au la unită i 3, 6 sau 9, se poate ca elevul să ajungă la o regulă greşită, prin analogie cu regula pentru divizibilitate cu 2, că ultima cifră ar trebui să fie multiplu de 3. Ulterior, există pericolul creării şi re inerii unei reguli eronate. Ca măsură, propunem oferirea unor contraexemple, pentru a sublinia şi elimina eroarea. Profesorul, pe baza experien ei sale profesionale, va trebui să identifice erorile care apar cel mai frecvent la o anumită temă şi să organizeze cât mai multe exemple şi contraexemple de utilizare pentru fiecare no iune, regulă, algoritm etc.

Principiul respectării unui ritm propriu de învă are este reflectat în programa de matematică de gimnaziu prin şase niveluri de competen e specifice, care sunt asociate fiecărui domeniu matematic şi care pot fi realizate progresiv de către un elev.

Ordonarea progresivă a competen elor specifice şi viziunea programei reflectă tendin a naturală a profesorilor de a alege sarcini ordonate logic, de la simplu la complex, de la particular la general, de la concret la abstract. Numai în măsura în care clasa de elevi devine receptivă, se poate utiliza o varietate de strategii de rezolvare de probleme, astfel fiind asigurată formarea unor deprinderi mentale înalte.

În final, trebuie subliniat faptul că rolul profesorului de la clasă rămâne determinant pentru implementarea cu succes a acestor modernizări privind viziunea de ansamblu a programei şcolare (Reys \& Reys, 1997, apud Cavanagh, 2006).

\section{Re eaua no ională a programei de matematică pentru gimnaziu}

Re eaua no ională este schematic prezentată în sec iunea programei denumită Con inuturi, sec iune în care sunt accentuate elementele de con inut cele mai cuprinzătoare, care includ alte no iuni de rang inferior. De exemplu, sub titlul general de număr natural se regăsesc no iuni precum: număr par, număr impar, succesor, predecesor, produs, termen, sumă, număr răsturnat etc. O parte dintre aceşti termeni pot fi utiliza i numai în măsura 
în care nivelul clasei permite acest lucru şi apar uneori sub forma unor liste în con inuturi (când s-a dorit să se evite un exces terminologic) sau se regăsesc în activită ile de învă are. În privin a simbolurilor care vor fi utilizate în clasă, programa recomandă introducerea lor cu mare precau ie, excesul de simboluri putând deveni un motiv de respingere a disciplinei. De exemplu, dacă pentru divizibilitate erau acceptate în programa anterioară două simboluri grafice (|, respectiv:), programa actuală recomandă utilizarea unuia singur, mai ales în clasa a $\mathrm{V}$-a.

Până în clasa a VI-a, conceptele elevilor sunt formate empiric, pe baza experien elor practice, propuse şi organizate de profesor. $\mathrm{Cu}$ cât varietatea este mai mare şi modul de organizare al exemplelor este mai bun, cu atât conceptele formate sunt mai exacte, în caz contrar, ,pot fi cuprinse accidental elemènte neesen iale particulare" (Catană \& Căprioară, 2016). În primele două clase de gimnaziu sunt evitate demonstra iile la geometrie, fiind agreate validările numerice, cum este, de exemplu, cazul teoremei lui Pitagora aplicate în triunghiuri dreptunghice. În cazul acestei teoreme, la clasa a VI-a nu se va face demonstra ia, ci se vor măsura (cu instrumentele geometrice adecvate) unghiul drept şi laturile triunghiurilor, pentru a se verifica rela ia dintre laturi; de asemenea, se recomandă să se arate prin contraexemple că rela ia respectivă nu se verifică în cazul triunghiurilor oarecare. Astfel, elevul va fi pregătit să în eleagă demonstra iile acestei teoreme şi va aplica rela iile respective în situa ii cotidiene sau în aplica iile de la fizică.

În primele două clase de gimnaziu se recomandă evitarea unor metode de rezolvare algebrice, programa punând accent pe metodele de rezolvare aritmetice reluate din clasele primare (pentru exersarea unor reprezentări); metodele algebrice de rezolvare a problemelor sunt introduse şi aprofundate în ultimii doi ani de gimnaziu.

Un alt aspect legat de reconfigurarea elementelor de con inut constă în transferarea unor capitole mari de con inut de la un an la altul, cu scopul descongestionării unor clase, considerate mai dificile. De exemplu, de la clasa a VIII-a, unde s-a luat în calcul un interval de timp necesar pregătirii pentru examenele na ionale, au migrat la clasa a VII-a unele elemente de con inut (ecua iile şi sistemele de ecua ii). De la clasa a V-a au fost transferate la clasa a VI-a mul imile, fiind considerate dificile, datorită simbolurilor 
utilizate, dar şi pentru a lăsa mai mult timp elevilor să se acomodeze cu trecerea la un nou ciclu de învă ământ.

\section{Competen e generale şi competen e specifice în matematica de gimnaziu}

Competen ele generale au rămas similare cu cele din programele anterioare, modificările fiind minore şi vizând mai degrabă formulările (comparativ cu alte programe şcolare, se poate constata că numărul de competen e specifice ataşate fiecărei competen e generale este aproximativ acelaşi). Structura utilizată pentru competen ele generale din programa de matematică de gimnaziu este similară cu cea a programelor de matematică pentru liceu, în uz la această dată.

Cele şase competen e generale din programă descriu tipuri de comportamente cognitive de complexitate diferită, care se formează progresiv în toată perioada şcolii gimnaziale. Definirea lor a avut în vedere o ierarhizare a achizi iilor elevilor la nivelul fiecărei clase (după modelul taxonomiei lui Bloom, cu modificări care au inclus elemente de dezvoltare cognitivă preluate de la modelul piagetian).

Prima competen ă, Identificarea unor date, mărimi şi rela ii matematice, in contextul în care acestea apar, se referă la receptarea informa iilor, având inclusă, ca opera ie mentală de bază, percep ia asupra obiectului, ideii, conceptului sau fenomenului studiat. Pentru acest nivel, elevul va identifica elemente noi în situa ii problematice, propuse de profesor. Această competen ă contribuie semnificativ la reorganizarea sferei conceptuale, pe baza observa iei şi prelucrării ulterioare a datelor.

A doua competen ă generală, Prelucrarea unor date matematice de tip cantitativ, calitativ, structural, cuprinse în diverse surse informa ionale, presupune interiorizarea informa iilor receptate şi prelucrarea primară a acestor date. Prelucrarea datelor, ca nivel elementar al aplica iilor, se realizează folosind o regulă sau o formulă dată, ori recurgând la reprezentări grafice (la geometrie). Această competen ă include următoarele categorii de opera ii: comparare, ordonare (de numere, mărimi de lungime, măsuri de unghiuri ş.a.m.d.), stabilirea unor rela ii (paralelism, perpendicularitate etc.), 
clasificări, calcule de bază. Nivelul presupune capacitatea elevilor de a discrimina date, de a observa elemente comune sau invarian $\mathrm{i}$.

Următoarea competen ă generală, Utilizarea conceptelor şi a algoritmilor specifici în diverse contexte matematice, corespunde nivelului de algoritmizare şi presupune cunoaşterea şi aplicarea unor metode de prelucrare secven ială a datelor. Este nivelul de exersare a procedeelor matematice. Această competen ă este o condi ie necesară continuării studiului matematicii în liceu. A alege corect o metodă, deşi pare un demers lipsit de importan ă, implică de fapt capacitate de decizie şi gândire anticipativă, precum şi capacitatea de a sesiza analogii între situa ii diferite şi de complexitate mai mare decât ceea ce se cerea pentru competen a anterioară. Un exemplu de procedeu, sugerat de programă la clasa a V-a, este identificarea celui mai mic multiplu comun (c.m.m.m.c.) a două numere naturale, prin enumerarea multiplilor fiecărui număr şi identificarea multiplilor comuni. Programa atrage aten ia că profesorii vor utiliza numere mici, astfel că procedeul se va concentra pe în elegere şi nu pe calcul. Similar se procedează şi pentru identificarea celui mai mare divizor comun (c.m.m.d.c.) a două numere naturale (sunt enumera i şi selecta i divizorii comuni). Profesorul va utiliza algoritmii de calcul la clasa a V-a, numai dacă nivelul clasei permite acest lucru (în cei $25 \%$ din timpul aflat la dispozi ia profesorului).

Capacitatea elevilor de a utiliza limbajul specific matematicii pentru descrierea unei situa ii matematice, prezentarea unei probleme, a unui demers de rezolvare sau a rezultatului ob inut sunt incluse în cea de-a patra competen ă generală, Exprimarea în limbajul specific matematicii a informa iilor, concluziilor şi demersurilor de rezolvare pentru o situa ie dată. Categoria de competen e vizată este comunicarea, iar prin această competen ă generală se urmăreşte formarea unui limbaj corect ştiin ific, utilizând termenii specifici matematicii. Elevii înva ă să îşi prezinte rezultatele, ideile matematice sau procedeele utilizate, folosind termenii şi simbolurile matematice şi aducând dovezi matematice pentru a-şi sus ine opiniile. Tot aici sunt incluse şi reprezentările pe axă (deoarece pentru realizarea unei sarcini de acest tip sunt necesare decodificări ale unor forme de scriere), precum şi anumite probleme practice de geometrie, care necesită o transformare din limbajul natural în limbaj matematic. 
Analizarea caracteristicilor matematice ale unei situa ii date este o competen ă care vizează prelucrarea secundară a datelor şi o interpretare la un nivel superior a unor situa ii problematice; aceasta poate să presupună compararea şi aprecierea unor rezultate sau concluzii finale şi raportarea lor critică la un context intra- sau interdisciplinar. La acest nivel pot fi stabilite metode şi strategii mai generale. De asemenea, la acest nivel se găsesc interpretările statistice ale unor seturi de date, estimările privind ordinul de mărime al rezultatelor unor calcule, estimări de arii sau volume (fără calcul); aceste activită i dezvoltă gândirea critică şi capacitatea decizională.

Ultima competen ă generală, Modelarea matematică a unei situa ii date, prin integrarea achizi iilor din diferite domenii, presupune opera ii precum aplicare, generalizare, particularizare, verificare, optimizare, transpunere sau adecvare la o situa ie reală. Această competen ă vizează o aplicare a matematicii în alte situa ii decât în cele exersate la curs, antrenând şi combinând cunoştin e sau proceduri învă ate la şcoală sau în afara şcolii. Simplificarea sau optimizarea unui algoritm, ca urmare a unor observa ii personale referitoare la context, sunt incluse în această competen ă generală. Competen a este de un nivel ridicat şi reflectă poten ialul creativ al elevului pentru această disciplină. Modelarea matematică este vizată prin activită i de transpunere a unei situa ii date în limbaj matematic, utilizând simboluri, rela ii, ecua ii sau inecua ii. La acest nivel regăsim şi formularea de probleme, precum şi realizarea unor conexiuni între diverse no iuni.

Competen ele specifice sunt, conform defini iei din programă, competen e de un nivel de generalitate mai redus, fiind de fapt particularizări ale competen elor generale pentru domeniile de con inut şi pentru nivelul de aşteptări la sfârşitul fiecărui an de studiu gimnazial. Sunt înso ite de activită i sau probleme tipice, pe care profesorii ar trebui să le prezinte în aşa fel încât să devină relevante pentru elevi. Prin analizarea competen elor specifice şi a elementelor de con inut, se pot defini şi alte tipuri de probleme care pot fi propuse într-o clasă de elevi; activită ile din programă sunt orientative şi pot fi completate sau înlocuite, în func ie de nivelul clasei.

Competen ele specifice (CS) sunt organizate progresiv de la un an la altul, existând un salt calitativ care vizează fie complexitatea no iunilor operate, fie complexitatea activită ilor solicitate. 
La o citire atentă a programei se poate constata că, uneori, un tip de activitate regresează de pe un nivel de competen ă pe altul, ca urmare a exersării sistematice şi a interiorizării sale. Un exemplu în acest sens este legat de divizibilitatea numerelor, respectiv aplicarea unui criteriu de divizibilitate, care la clasa a V-a este inclusă în nivelul 3 de competen ă, la CS 3.1. Utilizarea regulilor de calcul pentru efectuarea opera iilor cu numere naturale şi pentru divizibilitate, în timp ce în clasa următoare apare pe nivelul 2 de competen ă, la CS 2.1. Eviden ierea în exemple a rela iilor de apartenen $\breve{a}$, de incluziune, de egalitate şi a criteriilor de divizibilitate cu 2, 5, 10, 3 şi 9 in $N$.

Aplica iile propuse în programă explicitează competen ele specifice şi justifică încadrarea lor pe un anumit nivel. De exemplu, la CS 3.1, men ionată anterior, există un exemplu de activitate care include divizibilitatea (activitate pentru care se cere să se determine un număr natural, dacă sunt date o parte dintre cifrele numărului respectiv şi produsul cifrelor numărului). Problema implică identificarea unei metode de lucru adecvate şi de aceea este o sarcină considerată mai dificilă pentru clasa a V-a, pe când la clasa a VI-a o astfel de problemă este considerată mai simplă, datorită aplicării criteriilor de divizibilitate.

\section{Metode de abordare a elementelor de con inut din programă}

Dezvoltarea competen elor matematice poate fi asigurată dacă sunt îndeplinite câteva condi ii, cum ar fi existen a unor instrumente conceptuale, cunoaşterea unor practici sau procedee matematice, precum şi o comunitate de interese intelectuale care să sprijine învă area (Hiebert \& Grouws, 2007). Competen a matematică nu este un dat, ci poate fi privită mai degrabă ca o structură care se completează progresiv, odată ce structura no ională şi practicile matematice se multiplică şi se sus in reciproc, în grupuri sau clase de elevi interesate de studiu. Programa şcolară oferă cadrelor didactice un sprijin concret printr-o serie de sugestii metodologice, grupate pe clase de studiu, detaliind anumite experien e de învă are, potrivit specificului competen elor care trebuie formate pentru fiecare domeniu de cunoştin e.

Strategiile didactice agreate la această disciplină sunt cele care pun accent 
pe construc ia progresivă a cunoştin elor şi pe formarea continuă a deprinderilor. În măsura în care este posibil, sunt promovate şi dezvoltate parcursuri didactice diferen iate şi abordări interdisciplinare.

Pentru primii doi ani de gimnaziu este accentuată importan a unor metode active de tip învă are prin descoperire, învă are problematizată, învă are prin cooperare, metode care vor crea un climat ce încurajează interac iunea, angajarea elevilor în procesul de formare a competen elor specifice disciplinei matematică.

Se recomandă, în sugestiile metodologice, alternarea formelor de organizare a activită ilor (frontală, individuală, pe perechi şi în echipe), deşi în formularea activită ilor nu apare explicit forma lor de organizare, fiind lăsată la alegerea profesorului. Pentru sistematizarea no iunilor studiate pot fi utilizate diverse reprezentări grafice, gen diagrame, hăr i conceptuale etc.

Programa aduce ca noutate utilizarea la clasă a mijloacelor moderne de instruire TIC, care facilitează crearea unor reprezentări mentale mai bune, desfăşurarea unor lec ii interactive, dar şi o evaluare mai eficientă a elevilor. De exemplu, pentru unele activită i sunt sugerate aplica ii disponibile gratuit sau existente deja în unele şcoli, care pot fi utile în în elegerea unor concepte (cum ar fi Geogebra, care dispune de o bibliotecă de imagini 3D a corpurilor geometrice şi în care pot fi realizate transla ii şi rota ii spa iale, sec iuni în corpuri, grafice de func ii etc.) sau sunt făcute recomandări pentru un domeniu matematic studiat (cum ar fi folosirea unei aplica ii de calcul tabelar - gen Microsoft Excel ori OpenOffice - pentru domeniul Organizarea datelor, pentru calcul tabelar şi pentru reprezentări grafice).

Pentru toate clasele, este recomandată ca metodă discu ia, pentru a ob ine informa ii despre cum gândesc elevii cu privire la o anumită situa ie problematică sau pentru a identifica cauzele apari iei unor erori în ra ionamente sau în calcule. Este o metodă veche, dar eficientă, prin care profesorii detectează rapid discontinuită i în ra ionamentele elevilor.

Psihologul israelian Reuven Babai (2006) men ionează, de asemenea, câteva studii experimentale interesante referitoare la aplicarea unor reguli intuitive în cazul geometriei, studii pornite de la munca de pionierat a lui Efraim Fischbein privind rolul intui iei în matematică şi ştiin e. Acesta din urmă 
defineşte intui ia ca fiind o cunoaştere imediată care excede faptele, ca ,o teorie care implică o extrapolare dincolo de informa iile direct accesibile" (Fischbein, 1987, p.13 - tr.a.). Unul dintre experimentele amintite de Babai are la bază regula intuitivă numită de el ,mai mult A înseamnă mai mult B”. În cadrul acestui experiment, le-au fost prezentate unor elevi două figuri reprezentând practic acelaşi patrulater (Fig. 1), cu diferen a că celui de-al doilea (Fig. 2) i-a fost decupat un col , şi li s-a cerut să compare perimetrele celor două figuri. Peste $70 \%$ dintre elevii participan i la experiment au răspuns ca perimetrul figurii 1 este mai mare decât cel al figurii 2, deoarece ,,are suprafa a mai mare”, ,nu i-a fost tăiat niciun col ” etc. (Babai, 2006, p. 98). Acest procentaj ridicat de răspunsuri de tip mai mult $A$ (aria patrulaterului) înseamnă mai mult B (perimetrul patrulaterului) sugerează că această regulă intuitivă are un puternic efect asupra elevilor, în general.

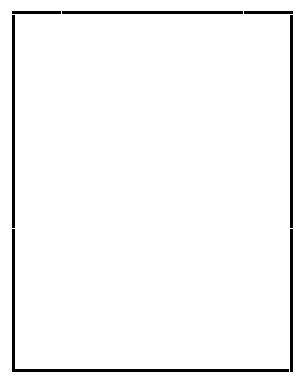

Figura nr. 1

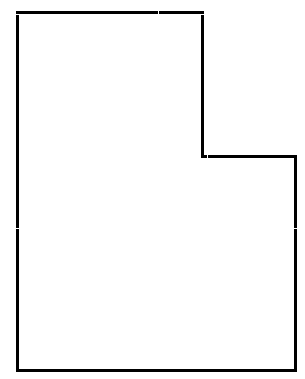

Figura nr. 2

Sursa: Babai, 2006, p. 98

Concluzia este că, datorită discu iilor care pornesc de la situa ii problematice pe care profesorul le poate prezenta în clasă, procentajul răspunsurilor eronate scade în timp, pe măsură ce elevii avansează în studiul unor scheme cognitive care pot corecta regulile intuite ini ial de elevi.

Rezolvarea de probleme este principala metodă utilizată în matematica de gimnaziu, fiind totodată şi un scop general al disciplinei. Metoda rezolvării de probleme implică elevii în propria învă are şi le oferă şansa de a se eviden ia, prin diverse idei sau solu ii personale generate. Elevii au ulterior posibilitatea de a organiza aceste idei şi solu ii după frecven a de apari ie a lor sau de a le 
ierarhiza după criterii precum elegan ă, acurate e sau eficien ă (raportate la resursele utilizate, respectiv timp şi efort). $\mathrm{Cu}$ prilejul rezolvării sarcinii respective, elevul are şansa să îşi utilizeze cunoştin ele şi deprinderile matematice acumulate. În timp ce elevii care au competen e înalte pot găsi solu ii mai bune pentru anumite situa ii particulare, elevii care au competen e mai joase pot găsi şi ei răspunsuri proprii, chiar dacă nu ajung la rezultatul final. Indiferent de nivelul de competen e la care ajung, prin rezolvarea de probleme elevii caută adevărul matematic, înva ă să fie riguroşi şi perseveren i, atât timp cât, în mod instinctiv, rămân motiva i să îşi justifice ac iunile şi să verifice mai apoi corectitudinea acestora.

În noua programă, eroarea este privită, poate pentru prima oară, ca o resursă didactică. Filosoful francez Gaston Bachelard, care a introdus conceptul de „obstacol epistemologic” afirma că, de fapt, ,cunoaştem contra unei cunoaşteri anterioare, distrugând cunoştin ele incorecte şi surmontând ceea ce, în spirit, constituie un obstacol în calea spiritualizării...” (Bachelard, 1938, apud Căprioară, 2011, p. 33). Ulterior, cercetători, pedagogi şi psihologi s-au preocupat de problematica obstacolelor şi a erorilor în didactica matematicii. Matematicianul francez Guy Brousseau pune în legătură obstacolul epistemologic cu motiva ia pentru învă area matematicii şi propune câteva strategii didactice pentru depăşirea lui (Brousseau, 2002). El sus ine că, pentru în elegerea unei no iuni abstracte, nu este suficientă numai o colec ie de situa ii în care să fie prezentată no iunea, să fie memorată teoria şi să fie făcute unele aplica ii, ci este necesară şi prezentarea unui ansamblu de concep ii şi idei rejectate (preconcep ii, concep ii greşite), precum şi studierea erorilor pe care urmează să le evităm. Măsurile didactice pe care le propune sunt: construirea sensului, utilizarea no iunilor respective în activită i de învă are pentru a fi în elese şi re inute, în elegerea particularită ilor no iunii respective, cunoaşterea limitelor no iunii şi a termenilor lingvistici asocia i.

Erorile reprezintă manifestarea obstacolelor epistemologice sau efectele lor. Psihologii consideră că, prin cunoaşterea lor, profesorii au şansa de a determina dificultă ile de în elegere şi erorile de ra ionament, acestea constituind ancore de la care îşi pot recalibra discursul şi parcursul didactic. Într-un studiu mai vechi realizat în Fran a, pe baza unor interviuri cu elevii de gimnaziu, au fost sistematizate principalele dificultă i care determină cele mai frecvente greşeli, valabile şi astăzi: lipsa unei perspective practice, concrete a problemelor 
prezentate şi o în elegere slabă, deficitară a acestor situa ii de învă are; incapacitatea elevilor de a aprecia rela iile matematice dintre elementele sarcinii de lucru (Hotyat, 1958).

Există erori tipice ataşate unor con inuturi de învă are, cu care cei mai mul i dintre profesorii de matematică s-au întâlnit destul de frecvent la clasă. Enumerăm câteva astfel de exemple: elevii nu disting frac ia principală, la frac iile supraetajate; la înmul irea a două puteri de numere naturale cu aceeaşi bază, înmul esc exponen ii în loc să îi adune, iar la împăr irea puterilor de numere naturale, împart exponen ii în loc să îi scadă; la geometrie, aplică teorema lui Pitagora pentru triunghiuri oarecare etc.

Gândirea critică, un alt aspect pe care programa pune accent, implică un tip de ra ionament care are la bază utilizarea unor criterii pentru conceptualizarea, evaluarea şi sintetizarea de idei şi informa ii din diverse surse şi constă, în cazul matematicii, în evaluarea unui ra ionament matematic, cu scopul de a-l ameliora. În procesul de apreciere critic , elevul include nu numai gânduri despre deprinderile mentale utilizate, dar şi credin e şi atitudini.

În privin a evalurii, sunt promovate în program atât metode tradi ionale (observarea sistematică, evaluarea activită ilor realizate ca teme, testări şi examinări orale), cât şi metode moderne pentru evaluare (cum ar fi metoda proiectelor, a portofoliilor sau autoevaluarea). Evaluarea este considerată ca fiind o componentă a demersului didactic, prin care profesorul tatonează nivelul la care sunt formate competen ele specifice din programe, identifică obstacolele cognitive apărute şi monitorizează progresul elevilor. De asemenea, prin intermediul evaluărilor, profesorul poate aprecia modul în care experien ele de învă are din afara şcolii se reflectă în învă area matematicii.

\section{Concluzii}

Succesul aplicării în practică a unei programe şcolare depinde, în principal, de o serie de factori, cum ar fi: în elegerea şi acceptarea ,spiritului” programei şcolare, participarea profesorilor la cursuri de formare, existen a unor manuale şi auxiliare didactice de bună calitate, o bună colaborare între profesorii din şcoală. 
Este necesar să se organizeze cursuri de formare focalizate pe implementarea curriculumului şcolar, care să eviden ieze diferen ele semnificative dintre programa anterioară şi cea în uz. Este recomandat ca cel pu in un profesor de specialitate dintr-o şcoală să participe la aceste formări, pentru ca, ulterior, ideile principale, cu exemple concrete, să fie dezbătute în cadrul catedrelor de matematică din şcoli.

Decodificarea programei şcolare induce anumite adaptări asupra planificării didactice, a metodelor de predare - învă are - evaluare şi de abordare a elementelor de con inut. Perspectiva intuitivă, propusă în programa de matematică până în clasa a VI-a, conduce la renun area la unele metode consacrate din matematica de gimnaziu, înlocuirea lor cu alte metode sau, în unele situa ii, mutarea lor de la un an la altul. Acest aspect al programei poate surprinde profesorii şi de aceea propunem elaborarea de ghiduri pentru profesori, care să detalieze aceste situa ii.

Eroarea tipică este considerată o sursă de învă are pentru profesor, care în elege astfel cum gândeşte un elev şi care sunt principalele obstacole de învă are. Profesorul poate (prin discu ii, exemple şi contraexemple, prin utilizarea unor materiale demonstrative etc.) să îşi reorganizeze situa iile de învă are sau discursul didactic, în acord cu nevoile de învă are ale elevului.

Nu în ultimul rând, programa invită profesorii la ingeniozitate didactică, pentru a genera situa ii de învă are deosebite, interdisciplinare sau care conectează matematica cu unele investiga ii ale elevilor sau cu interesele lor.

În cazul în care clasa permite, în limita a $25 \%$ din timpul disponibil, profesorul poate alege să prezinte şi să exerseze temele şi metodele algoritmice care au fost mutate sau eliminate din matematica primelor două clase de gimnaziu.

\section{Referin e}

- Babai, R. (2006). The Tendency to use Intuitive Rules among Students with Different Piagetian Cognitive Levels. In Novotná, J., Moraová, H., Krátká, M., \& Stehlíková, N. (Eds.). Proceedings 30th Conference of the International Group for the Psychology of Mathematics Education, Vol. 2, pp. 97-104. Praga: PME.

- Brousseau, G (2002). Theory of Didactical Situations in Mathematics (Didactique des Mathématiques, 1970-1990). Kluwer Academic Publishers. 
- Catană, L. (2010). Domeniul de competen ă cheie matematică şi elaborarea curriculară. Revista de pedagogie, nr. 58(3), 193-206.

- Catană, L. (2015). În ce măsură ne ajută matematica? Exemple de aplicare a matematicii: de la frac ii la alocarea resurselor într-o organiza ie. Revista de Pedagogie, 63(1), 57-68.

- Catană, L., \& Căprioară, D. (2017). Joc şi intui ie în predarea şi învă area matematicii la clasa a V-a. Bucureşti: Editura Universitară.

- Cavanagh, M. (2006). Implementing a reform-oriented mathematics syllabus: A survey of secondary teachers. In Novotná, J., Moraová, H., Krátká, M. \& Stehlíková, N. (Eds.). Proceedings 30th Conference of the International Group for the Psychology of Mathematics Education, Vol. 2, pp. 273-280. Praga: PME.

- Căprioară, D. (2011). Predarea şi învă area matematicii. Studiul obstacolelor şi al erorilor. Bucureşti: Editura Universitară.

- Dulamă, E. (2009). Cum îi învă ăm pe al ii să înve e. Teorii şi practici didactice. Cluj: Editura Clusium.

- Fischbein, E. (1987). Intuition in science and mathematics. Dordrecht, Olanda: Reidel.

- Gardner, H. (2005). Mintea disciplinată. Bucureşti: Editura Sigma.

- Hiebert, J., \& Grouws, D. A. (2007). The effects of classroom mathematics teaching on students' learning. In F. K. Lester (Ed.), Second handbook of research on mathematics teaching and learning (pp. 371-404). Charlotte, NC: Information Age.

- Hotyat, F.A. (1958). Educational Research in French-Speaking Countries of Europe. The School Review, 66(3), 313-328. https://doi.org/10.1086/442451.

- Ionescu, M., \& Bocoş, M. (Coord.) (2017). Tratat de didactică modernă. Piteşti: Editura Paralela 45.

- Munson, J. (2018). Two Instructional Moves to Promote Student Competence. Teaching children mathematics, 24(4). https://doi.org/10.5951/teacchilmath. 24.4.0244.

- Visser, J., \& Visser-Valfrey M. (Eds.) (2008). Learners in a Changing Learning Landscape: Reflections from a Dialogue on New Roles and Expectations. Ed. Springer Science.

- Programa şcolară pentru disciplina Matematică, clasele a V-a - a VIII-a. Bucureşti: Ministerul Educa iei Na ionale, 2017; disponibilă la: http:// programe.ise.ro/Portals/1/Curriculum/2017-progr/24-Matematica.pdf (accesată la 10.07.2018).

- Repere pentru proiectarea şi actualizarea curriculumului na ional. Document de politici educa ionale. Bucureşti: Institutul de Ştiin e ale Educa iei. Versiune de lucru Mai 2016; disponibilă la: http://www.ise.ro/wp-content/uploads/2015/ 07/Document-politici-curriculum_draft_mai_2016.pdf (accesată la 24.06.2018). 
The online version of this article can be found at: http://revped.ise.ro/category/2018-en/

\section{(cc) $\mathrm{BY}-\mathrm{NC}-\mathrm{SA}$}

This work is licensed under the Creative Commons Attribution-NonCommercial-ShareAlike 4.0 International License.

To view a copy of this license, visithttp://creativecommons.org/licenses/by-ncsa/4.0/ or send a letter to Creative Commons, PO Box 1866, Mountain View, CA 94042, USA.
Versiunea online a acestui articol poate fi găsită la:http://revped.ise.ro/category/2018-ro/

\section{$( c c ) \longdiv { B Y - N C - S A }$}

Această lucrare este licen iată sub Creative Commons Attribution-NonCommercial-ShareAlike 4.0 International License.

Pentru a vedea o copie a acestei licen e, vizita $i$ http://creativecommons.org/licenses/by-nc-sa/4.0/ sau trimite i o scrisoare către Creative Commons, PO Box 1866, Mountain View, CA 94042, SUA. 